\title{
Properties of controlled low-strength material made using industrial waste incineration bottom ash and quarry dust
}

\author{
Sivakumar Naganathan , Hashim Abdul Razak, Siti Nadzriah Abdul Hamid
}

The scheduled industrial waste generation in Malaysia in the year 2009 is $1,705,308$ metric tonnes [1], major components of the wastes are from dross, slag, clinker, ash, gypsum, oil and hydrocarbon. These wastes must be properly managed and disposed without causing any harmful environmental effects. Around 126,288 metric tonnes of industrial wastes are treated by Kualiti Alam Sdn Bhd, Malaysia. Incineration of these wastes produces around 25,000 tonnes of bottom ash (BA) which are sent to secured landfills. But disposal by land filling is not a sustainable solution.

Hence various methods of using the bottom ash need to be developed. Incineration bottom ash, if reused, will ensure sustainability, reduce pollution and environmental degradation, generate revenue, and preserve the natural virgin resources [2]. One of the ways of using the industrial waste incineration bottom ash is to use them as controlled low-strength material (CLSM). CLSM, in its simplest form, is slurry made by mixing sand, cement, ash, and water. ACl committee 229 [3] defines CLSM as a material having a compressive strength of $8.3 \mathrm{MPa}$ or less. It is self compacting, flowable, and used primarily as replacement for soil and structural fillings like bridge abutment, pipeline bedding, tilt-up construction, foundation backfill, filling abandoned mines, under slab voids, and sequential excavations in contaminated soil. Many waste materials have been successfully employed in CLSM applications. Dry scrubber ash, fly ash, clean coal ash, high-fines limestone screenings, recycled glass are to name a few [4]. Materials like scrap tyre rubber [5], fluidized bed combustion ashes [6], and recycled concrete aggregate [7] were also used in CLSM applications. Tests done by the authors earlier on the use of incineration bottom ash as CLSM showed promising results [8,9], and there were minor problems like stability. Quarry dust (QD) is crushed dust, produced during the breaking of stone boulders in stone crushers for producing coarse aggregates. The quarry dust consists of excess fines and is considered as a waste material which is normally dumped in bulk quantities around the quarry plants and causes environmental pollution. Quarry dust has been used successfully in concrete, pavement 
construction, and in CLSM [10-13]. Use of quarry dust in

bulk quantities will greatly mitigate the environmental problems

caused by dumping of quarry dust in open lands.

The combination of industrial waste incineration bottom ash

and quarry dust in CLSM application has not been carried out

before. Quarry dust, being fine material, is supposed to enhance

the performance of CLSM made using the bottom ash. The objective

of this paper is to study various engineering properties of

CLSM made using industrial waste incineration bottom ash and

quarry dust. Various mix proportions of CLSM were developed

using bottom ash, quarry dust, cement and water. Tests were done on CLSM mixtures in fresh and hardened states and the results

discussed. The significance of this research is the attempt of using

quarry dust and industrial waste incineration bottom ash to develop

CLSM. Both are waste materials and hence will contribute to

sustainability.

Experimental methods

Materials used

Ordinary Portland cement conforming to Malaysian Standard

MS 522 Part 12003 [14] was used in this investigation. Bottom

ash was obtained from the industrial waste incineration plant

operated by Kualiti Alam Sdn Bhd, Malaysia. The raw materials that

are incinerated include chemical wastes, wastes from electrical,

electronic, and metal industries. The bottom ash contains particles

of various sizes from fine powder to $60 \mathrm{~mm}$. The bottom ash was

first dried in an oven at 105 _C until constant mass, and then sieved

through a $10 \mathrm{~mm}$ sieve to eliminate unsuitable material and particles

larger than $10 \mathrm{~mm}$ size. Quarry dust was also prepared in the

same manner like the bottom ash for use in this investigation. The

physical properties of bottom ash and quarry dust are given in Table

1 and the chemical composition of cement, quarry dust, and

bottom ash is shown in Table 2. The specific gravity of bottom

ash is 1.83 and the specific gravity of quarry dust is 2.59 . The quarry

dust is denser and heavier than bottom ash. The grading curves

for bottom ash and quarry dust are given in Fig. 1. It is indicated

that the grading of both materials fall within the ranges given in

BS 882:1992 [15].

Mix proportions and sample preparation 
The mix proportions used in the investigation are shown in Table

3. The formulations were calculated by mass and volume on solid

materials at oven-dry condition using a back calculation

procedure based on measurements made on the fresh mixture for

density, density values of raw materials, and the water content

needed for flowability requirements. The bottom ash, quarry dust,

and cement were first placed in a tilting type mixer, and dry mixed

for one minute. Sufficient quantity of water was then added and the

contents mixed for two minutes. The sample was then tested for

flow consistency as per ASTM D 6103 [16] standard test method

for flow consistency of CLSM. According to ACI 229R [3], the CLSM

is considered flowable if the spread diameter is at least $200 \mathrm{~mm}$.

Hence the spread diameter for all the CLSM mixtures was kept constant

at $200 \pm 20 \mathrm{~mm}$. Water content was then adjusted until the

flow was $200 \pm 20 \mathrm{~mm}$. The contents were then mixed for another $2 \mathrm{~min}$. CLSM was then filled in $70.7 \mathrm{~mm}$ cube moulds, and about

$450 \mathrm{ml}$ in a $500 \mathrm{ml}$ plastic measuring jar for stability measure ments. The moulds were not subjected to vibration, but tapped at

the sides to remove entrapped air. Cubes were kept covered with

wet burlap in the laboratory environment for one day, and then

transferred to the curing environment which is maintained at

$22 \_C$ and $95 \%$ relative humidity. The cubes were removed from

the moulds on the day of testing.

Full text available at :

http://www.sciencedirect.com/science/article/pii/S0261306911004924

http://ac.els-cdn.com/S0261306911004924/1-s2.0-S0261306911004924-main.pdf? tid=4fd4dba6-781f-11e3a1e3-00000aab0f02\&acdnat $=1389156343$ f1f9bc65223fcb60ff135daf288b52c7 